\author{
Maciej Smuk \\ Uniwersytet Warszawski \\ https://orcid.org/0000-0002-0911-9046 \\ m.smuk@uw.edu.pl
}

\title{
Czego pragnq przyszli filolodzy... Wyniki badania pilotażowego na temat świadomości wyboru i oczekiwań studentów filologii
}

\author{
What future philologists desire... The results of a pilot study \\ of the awareness of philology students' choices and expectations
}

The main of this article is to present the results of a pilot study carried out among 476 students of selected foreign languages at Warsaw University. The research covered the following issues: (1) students' interest in various courses included in philology studies (literature, linguistics, foreign language didactics, etc.); (2) the dominant motivation for undertaking philological studies and (3) students' initial career plans. The research is diagnostic and descriptive and it will be continued at over a dozen Polish universities. The main goal of this project is to build a social representation of foreign language studies in Poland today. The Polish Association of Modern Languages (PTN) is a patron of the study.

Keywords: students, foreign language departments, profile, awareness, expectations, plans

Słowa kluczowe: studenci, filologie, profil, świadomość, oczekiwania, plany

\section{Wprowadzenie: kontekst badania}

Wedle obiegowej opinii współcześnie studia filologiczne powinny istotnie zmieniać swój profil, stawać się bardziej interdyscyplinarne. Niejednokrotnie 
rekomenduje się łączenie filologii obcych z innymi kierunkami. Potrzeby zmian motywuje się nowymi wyzwaniami gospodarczymi i społecznymi, ewoluującymi wymaganiami pracodawców lub - co czasami podnoszone jest jako kluczowy argument - nowymi (chociaż bliżej nieokreślonymi) oczekiwaniami studentów rozpoczynających studia filologiczne. W rzeczywistości jednak trudno stwierdzić, co jest faktem, a co złudzeniem, jakie wnioski wynikają z badań, a jakie z potocznych obserwacji, co jest poglądem czy odczuciem wykładowców, a co opinią studentów itd.

W ciągu ostatnich kilkunastu lat były prowadzone lokalne badania zmierzające do ustalenia - z różnorodnych perspektyw - profilu studenta filologii (np. Wróblewska-Pawlak, Okęcka, 2000; Paprocka-Piotrowska, Knieja, 2009; Werbińska, 2012; Biernacka-Licznar, 2013; Dańko, Wieszczeczyńska, 2013; Lankiewicz, 2013; Baran-Łucarz, 2014; Jaroszewska, 2014; Nerlicki, 2014; Pawlak, Mystkowska-Wiertelak, Bielak, 2014; Sowa, Mocarz-Kleindienst, Czyżewska, 2015; Pudo, 2017). Odrębną i ważną, także ilościowo, grupę stanowią publikacje o kształceniu filologicznym przyszłych nauczycieli języków obcych. Niemniej jednak na temat współczesnych studentów filologii nadal brakuje danych bardziej globalnych i reprezentatywnych, a także istotniejszych ilościowo. Luki te stały się spiritus movens omówionego w artykule badania i szerzej - ogólnopolskiego projektu badawczego, o którym mowa niżej. Wyniki takich badań mogą czy wręcz powinny znaleźć odbicie w tym:

- jak definiowana będzie rola jednostek kształcących przyszłych filologów;

- jakie są społeczne i/lub ekonomiczne potrzeby z punktu widzenia rozwijanych kompetencji;

- jakie obszary bądź jakie tematy mogłyby zostać włączone do kształcenia filologicznego;

- jakim ewolucjom mogą zostać poddane formy kształcenia itd.

W tekście zostaną przedstawione wyniki badania na temat świadomości wyboru kierunku studiów i wstępnych oczekiwań studentów filologii. Sformułowano w nim następujące problemy badawcze:

1. Które obszary tradycyjnego kształcenia filologicznego cieszą się największym zainteresowaniem wśród studentów rozpoczynających studia oraz jakie przyczyny leżą u podstaw tego zainteresowania?

2. Jakie motywy były kluczowe przy podejmowaniu decyzji o rozpoczęciu studiów filologicznych?

3. Jakie są wstępne plany zawodowe studentów rozpoczynających studia filologiczne? 
W badaniu zastosowano kwestionariusz, który dzielił się na trzy sekcje tematyczne, korespondujące $z$ trzema powyższymi problemami badawczymi. W sumie zawierał on siedem pytań oraz część, w której student sam mógł zadać dowolne pytania dotyczące studiów. Kwestionariusz miał charakter diagnostyczno-opisowy, zatem udzielone odpowiedzi nie powinny podlegać ocenie w kategoriach dobra/zła.

Badanie omówione w artykule zostało zrealizowane w roku akademickim 2018/2019. Wzięło w nim udział 476 studentów różnych filologii Wydziału Neofilologii Uniwersytetu Warszawskiego, tj. angielskiej (134 respondentów), fińskiej (18), hiszpańskiej (75), niemieckiej (78), romańskiej (francuskiej) (103), węgierskiej (17), włoskiej (51). Ogółem było to 354 studentów studiów licencjackich (R1R354) i 122 studentów studiów magisterskich (R355-R476). Ze względu na cele badanie wykonano wśród studentów pierwszego roku studiów licencjackich i magisterskich, z reguły jeszcze przed rozpoczęciem zajęć, czyli podczas tzw. dni adaptacyjnych. Ma ono charakter pilotażowy i jest częścią projektu o roboczej nazwie NEOFILOLOG 2020, który w roku akademickim 2019/2020 i 2020/2021 będzie realizowany na filologiach obcych kilkunastu polskich uniwersytetów ${ }^{1}$.

Żeby ułatwić lekturę tekstu i analizę danych, dyskusja na temat rezultatów, w tym ich interpretacje, będą towarzyszyć bezpośrednio prezentacji wyników.

\section{2. Świadomość wyboru}

Pierwsza część kwestionariusza dotyczyła wstępnej wiedzy respondentów o podejmowanych studiach i zainteresowania nimi. Punktem wyjścia była chęć uzyskania informacji na temat obszarów tradycyjnego kształcenia filologicznego (dydaktyka języków obcych, językoznawstwo, kultura, literatura, nauka języka, traduktologia, inne), które cieszą się największym zainteresowaniem - chodziło o bardzo wstępne wyobrażenia studentów. Respondenci zostali poproszeni o zaznaczenie dwóch obszarów. W tab. 1 przedstawiono wyniki ilościowe.

Poniżej streszczono tendencje dotyczące powodów wyboru danych obszarów.

W przypadku kultury dominowały bardzo ogólne sformułowania, ale bez wątpienia to motywy o charakterze integrującym wydają się kluczowe: zainteresowanie kulturą, fascynacja różnorodnością, możliwość lepszego rozumienia świata dzięki poznaniu kultury obcej itd., np.:

\footnotetext{
${ }^{1}$ Badanie na temat oczekiwań studentów rozpoczynających studia i satysfakcji studentów kończących studia prowadzą: dr Monika Grabowska z Uniwersytetu Wrocławskiego, dr hab. Maciej Smuk z Uniwersytetu Warszawskiego i prof. ucz. dr hab. Magdalena Sowa z Uniwersytetu Marii Curie-Skłodowskiej w Lublinie. Patronat nad badaniem objęło Polskie Towarzystwo Neofilologiczne.
} 
- Dogłębnie jq poznajqc na zajęciach, łatwiej później odnaleźć się w społeczeństwie (R4);

- $\quad$ Kultura $]$ - otwiera to umyst (R68);

- Jestem ciekawa świata, lubię poznawać i rozumieć różne spojrzenia na problemy (R228).

\begin{tabular}{|l|c|c|c|}
\hline Obszar zainteresowań & Łącznie $^{2}$ & Studia licencjackie & Studia magisterskie \\
\hline Dydaktyka języków obcych & $15,7 \%(105)$ & $9 \%(64)$ & $16,8 \%(41)$ \\
\hline Językoznawstwo & $16,5 \%(158)$ & $16,6 \%(118)$ & $16,3 \%(40)$ \\
\hline Kultura & $24,7 \%(236)$ & $25,7 \%(182)$ & $22,1 \%(54)$ \\
\hline Literatura & $14,9 \%(142)$ & $13,8 \%(98)$ & $18 \%(44)$ \\
\hline Nauka języka & $19,8 \%(189)$ & $24,1 \%(171)$ & $7,3 \%(18)$ \\
\hline Traduktologia & $11,2 \%(107)$ & $9 \%(64)$ & $17,6 \%(43)$ \\
\hline Inne & $1,5 \%(15)$ & $1,5 \%(11)$ & $1,6 \%(4)$ \\
\hline
\end{tabular}

Tabela 1: Wstępne zainteresowanie obszarami kształcenia filologicznego.

Ponadto pojawiły się argumenty o innym ciężarze gatunkowym: (a) studia na filologii idą w parze ze studiami na innym kierunku lub rodzajem pracy, np. filmoznawstwem, sztukami pięknymi, pracą w teatrze, byciem muzykiem oraz (b) studia na filologii mogą przygotować do emigracji lub wyjazdu czasowego, np.:

- Uważam, że może to być ciekawa umiejętność dajqca możliwość komfortowego wyjazdu (osiedlenia się) w Finlandii (R163);

W przypadku nauki języka górowały ogólne zdania o jej praktycznej istotności i atrakcyjności samej w sobie, np.

- Posługiwanie się językami obcymi to ważna umiejętność we współczesnym świecie (R293).

Zwróciły uwagę wypowiedzi studentów filologii fińskiej i węgierskiej, według których o atrakcyjności języków (fińskiego i węgierskiego) decyduje to, że są trudne i niepopularne, $\mathrm{np}$.:

- Język węgierski jako język niszowy jest coraz częściej poszukiwanq umiejętnościq u kandydatów do podjęcia pracy w wielu instytucjach (R178);

- ... rozwój lotnictwa na rynku węgierskim i brak specjalistów ze znajomościq węgierskiego ... (R176).

\footnotetext{
${ }^{2} 476$ respondentów zaznaczyło dwa obszary, zatem suma to 952 (708 - studia licencjackie i 244 - studia magisterskie).
} 
Gdy mowa o językoznawstwie, przeplatały się motywy integrujące (np. zainteresowanie procesami językoznawczymi, chęć poznania zasad słowotwórstwa, fascynacja genezą języków i związkami między nimi) z motywami instrumentalnymi (wykorzystanie wiedzy językoznawczej w pracy tłumacza, specjalisty NLP, programisty itd.).

Także w przypadku traduktologii podnoszono aspekty praktyczne, związane z przygotowaniem do pracy zawodowej.

Co się tyczy dydaktyki języków obcych, dominowały przesłanki praktyczne (głównie chęć uzyskania uprawnień do nauczania), ale wymieniano również motywy typu integrującego, np.:

- Chcę nauczać języka, aby przyczynić się do ogólnego rozwoju społeczeństwa (R186);

- Miałam do czynienia z różnymi nauczycielami, z przyjemnościq pomniejszyłabym grono tych mniej kompetentnych (R421).

W przypadku literatury zdecydowanie przeważały motywy integrujące (zainteresowanie, pasja itd.), niemal każdy respondent mówiący o literaturze podał z pozoru prozaiczne czerpanie radości z czytania, np.:

- Od zawsze pochłaniałam ksiq̨żki, do dzisiaj czytanie sprawia mi duża przyjemność (R470);

- Jest to moje zainteresowanie, pasja i zgłębianie wiedzy o niej [literaturze] przynosi mi niesamowitq radość i satysfakcję (R15);

- Literatura jest afirmacjq ludzkiej duszy (R366).

Warto przyjrzeć się głównym różnicom między odpowiedziami studentów studiów licencjackich i magisterskich.

Zasadniczo typy motywów w odniesieniu do wszystkich obszarów pokrywały się. Na studiach magisterskich doszła chęć kontynuowania badań związanych z tematyką pracy licencjackiej. Zwiększyła się też liczba studentów zainteresowanych traduktologią, za to zmniejszyła się liczba osób zainteresowanych nauką języka jako taką. W przypadku dydaktyki języków obcych dalej dominowały powody praktyczne, tj. podniesienie i/lub uzupełnienie kwalifikacji - rozporządzenia ministerialne narzucają bowiem określony tryb i warunki kształcenia przyszłych nauczycieli języków obcych. Wielu respondentów już pracuje w zawodzie nauczyciela, przede wszystkim są to studenci filologii angielskiej; oni też doprecyzowywali swoje oczekiwania, np.:

- Chcę zdobyć wiedzę z zakresu [...] różnic indywidualnych między uczniami (R382);

- Miałam praktyki w szkole i widzę, że wiedza z dydaktyki jest potrzebna w nauczaniu (R468). 
Studenci studiów magisterskich są również bardziej świadomi zazębiania się różnych dyscyplin, np. wiedza językoznawcza ma pomóc w analizie tekstów literackich lub w tłumaczeniach. Ogólnie rzecz biorąc, powody przedstawiane przez studentów studiów magisterskich były bardziej skonkretyzowane, np.:

- elementy brytyjskiej i amerykańskiej kultury obecne w naszym kraju (R379);

- strategie przekładu (R 399);

- wpływy kultury popularnej na światopoglad (R401);

- To, jak mówimy, kształtuje to, jak myślimy - interesuje mnie szczególnie analiza dyskursu (R476);

- Chciałbym poszerzyć znajomość literatury francuskiej XIX i XX wieku (R456);

- Interesuje mnie literatura hiszpańska na tle literatury wschodnioeuropejskiej (R422).

W tej samej części kwestionariusza zamieszczono pytanie dotyczące zapoznania się z ofertą danego kierunku, np. podczas podejmowania decyzji o studiach. Ogólnie wyniki te można - zgodnie z przewidywaniami - streścić następująco: największa liczba respondentów zapoznała się z profilami (ścieżkami) kształcenia na wybranej przez siebie filologii $(92,4 \%, \mathrm{tj} .440$ respondentów) i programami studiów $(92 \%$, tj. 438). W dalszej kolejności uplasowały się: programy mobilności $(58,8 \%, \mathrm{tj} .280)$, uprawnienia do nauczania $(56,3 \%$, tj. 268), struktura organizacyjna jednostki $(53,5 \%$, tj. 255$)$, praktyki zawodowe (41,8\%, tj. 199), sylabusy przedmiotów ( $37,6 \%, \mathrm{tj} .179)$, badania naukowe prowadzone w jednostce $(33,8 \%, \mathrm{tj} .161)$, profile pracowników $(31,7 \%, \mathrm{tj} .151)$, historia jednostki $(30,2 \%, \mathrm{tj}$. 144). Nie ma istotnych różnic między odpowiedziami studentów studiów licencjackich i magisterskich - największa różnica procentowa dotyczy zainteresowania profilami pracowników danej jednostki (27,1\%, tj. 96 studentów studiów licencjackich versus 45\%, tj. 55 studentów studiów magisterskich) i jej historią (25,7\%, tj. 91 studentów studiów licencjackich versus $43,4 \%, \mathrm{tj} .53$ studentów studiów magisterskich).

\section{Motywy wyboru i wstępne oczekiwania}

Druga sekcja badania dotyczyła motywów podjęcia studiów i oczekiwań (także nadziei) związanych z nimi.

W pierwszej kolejności respondenci zostali poproszeni o podanie trzech najistotniejszych przyczyn podjęcia studiów na danej filologii. Ograniczenie się do trzech motywów było celowe - mianowicie tak sformułowane pytanie obliguje respondenta do dokonania selekcji i wyłonienia czynników warunkujących wybór studiów, nie tylko wpływających na niego. 
Poniżej wypunktowano dominujące tendencje (ponad 10\% odpowiedzi):

- nauka języka obcego (języków obcych), w tym często przywoływana możliwość uczestniczenia w zajęciach prowadzonych w języku obcym $-48,5 \%$, tj. 231 respondentów;

- wysoki poziom nauczania (wysoka lokata w rankingach, prestiż kierunku, dobre opinie itp.) - 34,2\%, tj. 163 respondentów;

- nauka o kulturze; w tej grupie wymieniono też konkretne dyscypliny, np. sztukę, kinematografię, muzykę, kulturę popularną $-23,9 \%$, tj. 114 respondentów;

- chęć rozwijania zainteresowań i czerpania przyjemności ze studiów, głównie w związku z samą nauką języków obcych (symbolicznie argument ten można ująć w zdaniu Lubię uczyć się języków) - 23,7\%, tj. 113 respondentów ${ }^{3}$;

- plany zawodowe (rodzinne) związane z wyjazdem za granicę $-18 \%$, tj. 86 respondentów;

- oferta zajęć na danym kierunku: bogata, ciekawa, istnienie różnych specjalizacji itp. $-11,3 \%$, tj. 54 respondentów;

- szerokie perspektywy zawodowe, które oferuje ten typ studiów, np.: uniwersalność kierunku - jego ukończenie daje wiele możliwości (R43), otwarta furtka (R391), możliwość zdobycia kontaktów, które pomogłyby $w$ dalszym rozwoju kariery (R444) $-11,3 \%$, tj. 54 respondentów;

- lokalizacja jednostki prowadzącej kierunek -10,7\%, tj. 51 respondentów.

Dalsze pozycje (mniej niż 10\%) zajęły: możliwość rozwoju humanistycznego, poznanie literatury obcej, programy mobilności międzynarodowej, kontynuacja nauki języka obcego z liceum, możliwość samodzielnego budowania planu zajęć itd.

Z punktu widzenia różnic między motywami studentów studiów licencjackich i magisterskich warto powiedzieć, że częściej była mowa o nauce języka obcego (języków obcych) i zainteresowaniu kulturą w grupie studentów studiów licencjackich. Wyłącznie respondenci z tej grupy podali jako przyczynę podjęcia studiów przyjemność nauki języków. Oni też zaakcentowali szerokie perspektywy i rozwój ogólny. Studenci studiów magisterskich częstokroć wybrali studia ze względu na ich wysoki poziom, a nawet renomę i ciekawą ofertę przedmiotową/specjalizacyjną. 30,3\% respondentów (tj. 37 osób) z tej grupy powiedziało o „naturalnej potrzebie” kontynuowania studiów w tej samej dyscyplinie.

\footnotetext{
${ }^{3}$ Motywy nauka języka obcego i przyjemność wynikajqca z nauki języka obcego nie są, zgodnie z moją interpretacją, równoznaczne i dlatego rozpatruję je oddzielnie. Gdy mowa o nauce języka obcego, może bowiem chodzić głównie np. o rozwijanie wybranych kompetencji w celu znalezienia atrakcyjnej pracy w zagranicznej firmie czy możliwość swobodnego podróżowania.
} 
Uzupełnieniem pytania o motywy podjęcia studiów filologicznych było pytanie o zagadnienia, którymi w największym stopniu interesują się studenci I roku. Założyłem, że nawet jeśli odpowiedzi częściowo pokryją się, to będzie możliwe wyłonienie nowych i bardziej skonkretyzowanych oczekiwań.

Poniżej wypunktowano dominujące tendencje (ponad 10\% odpowiedzi):

- język obcy, a najczęściej wskazywano na zajęcia poświęcone rozwijaniu sprawności mówienia, zajęcia z języka specjalistycznego i zajęcia dotyczące różnych wariantów geograficznych danego języka, np. dialektów - 56,0\%, tj. 267 respondentów;

- $\quad$ kultura, tu najczęściej mówiono o kulturze współczesneji o sztuce, a w dalszej kolejności wymieniono: kino, modę, sport, geografię, gospodarkę, politykę, prawo, kuchnię, stosunki polsko-... -38,4\%, tj. 183 respondentów;

- literatura, przede wszystkim literatura współczesna - 29,8\%, tj. 142 respondentów;

- historia $-14,9 \%$, tj. 71 respondentów;

- językoznawstwo (nauka o języku), a najczęściej mówiono o historii danego języka i o analizie dyskursu -14,4\%, tj. 69 respondentów;

- $\quad$ szeroki zakres zagadnień związanych z dydaktyką języków obcych, np. andragogika, psychopedagogika, ocenianie, trudności w nauczaniu, nowe technologie w nauczaniu $-10,9 \%$, tj. 52 respondentów.

Na dalszych pozycjach (mniej niż 10\%) uplasowały się: gramatyka, fonetyka (fonologia, wymowa), drugi język obcy, kompetencje akademickie (czytanie, pisanie), filozofia.

Trzeba też zauważyć, że około 30\% respondentów w ogóle nie odpowiedziało na to pytanie, co może sugerować brak konkretnych oczekiwań względem studiów filologicznych lub niemożność określenia preferencji z powodu, który można by określić jako „nieznajomość terenu”.

Warto też przeanalizować główne różnice między odpowiedziami studentów studiów licencjackich i magisterskich. Kwestie związane z nauką języka jako taką - głównie nauką gramatyki i fonetyki - były częściej wymienione przez studentów I roku studiów licencjackich. Studenci I roku studiów magisterskich, gdy mówili o nauce języka, kładli nacisk na język specjalistyczny i zajęcia tłumaczeniowe. Według uzyskanych danych na studiach magisterskich minimalnie wzrasta zainteresowanie literaturą, zwłaszcza literaturą XX i XXI wieku. Więcej respondentów wyraziło też głód wiedzy z dydaktyki sensu largo (studenci studiów magisterskich wymienili konkretne zagadnienia). Wyłącznie w tej grupie była mowa o zajęciach poświęconych kompetencjom akademickim i nauce drugiego języka obcego (w przypadku iberystów chodziło o drugi język Półwyspu Iberyjskiego). 


\section{Wstępne plany zawodowe}

Trzecia sekcja badania dotyczyła bieżących (czyli bardzo wstępnych) planów zawodowych studentów.

10,2\%, tj. 49 respondentów nie odpowiedziało na pytanie, co może być zrozumiałe, biorąc pod uwagę ich etap życia. Poniżej przedstawiono zaś najczęstsze odpowiedzi w porządku malejącym:

- tłumacz $-53,7 \%, \mathrm{tj} .256$ respondentów;

- nauczyciel/lektor - 25,4\%, tj. 121 respondentów (w tym 13 osób podało pracę $w$ charakterze nauczyciela akademickiego);

- praca w firmie (praca w korporacji, praca w biznesie itp. - bez podania branży czy stanowiska) $-7,3 \%, \mathrm{tj}$. 35 respondentów;

- turystyka (pilot wycieczek, przewodnik, rezydent) $-4,2 \%$, tj. 20 respondentów;

- dyplomacja - 3,5\%, tj. 17 respondentów;

- marketing/reklama/public relations $-3,1 \%$, tj. 15 respondentów;

- instytucja kultury $-2,9 \%$, tj. 14 respondentów;

- dziennikarstwo/media $-2,3 \%$, tj. 11 respondentów ${ }^{4}$.

Wśród odpowiedzi respondentów znalazły się również stwierdzenia bardziej ogólne, ale uwypuklające wolę wykonywania pracy związanej z użyciem danego języka i/lub wiedzy humanistycznej, np.:

- Nie wiem jeszcze, ale znajq̨c języki, możliwości jest dużo (R312);

- Zawód zwiqzany z interpretowaniem różnych zjawisk społecznych i kulturalnych (R407);

- Praca wymagajqca dobrej znajomości literatury i/lub kultury krajów anglosaskich (R412).

Intencją badania było też stwierdzenie, czy - zgodnie ze wstępnymi przypuszczeniami studentów - studia filologiczne mogą przygotować do wskazanego zawodu lub rodzaju pracy. Gdy była mowa o zawodach tłumacza i nauczyciela, najczęstsze wybory to „zdecydowanie tak” i „raczej tak”. W przypadku

\footnotetext{
${ }^{4}$ Inne sektory, wymienione przez 1-3 respondentów, to m.in.: aktorstwo, architektura, branża medyczna (w tym lekarz), branża motoryzacyjna, branża muzyczna (wokalista, producent), branża ochroniarska, choreografia latynoamerykańskich tańców towarzyskich, filozofia, grafika, księgowość, lotnictwo (nawigator, personel pokładowy), negocjacje, organizacja wydarzeń, organizacje pozarządowe, pisarstwo, pomoc humanitarna, projektowanie mody, prowadzenie hotelu dla psów, psychologia, reżyseria filmowa, spedycja, wojsko (żołnierz zawodowy), zarządzanie zasobami ludzkimi.
} 
zawodów, które nie korespondują z sylwetką studenta/absolwenta filologii, respondenci wybierali odpowiedzi „zdecydowanie nie” $\mathrm{i}$ - rzadziej - „raczej nie”. Te wybory mogą sugerować, że - wbrew obiegowej opinii - nie każdy student oczekuje bardzo konkretnego, wręcz warsztatowego przygotowania do pracy zawodowej.

Jeżeli chodzi o różnice między odpowiedziami studentów obu stopni, to najistotniejsze dotyczą zawodu nauczyciela - tylko 17,7\% studentów studiów licencjackich ( 63 osoby) i aż 47,5\% studentów studiów magisterskich (58 osób) zadeklarowało wykonywanie tego zawodu. Pozostałe różnice nie przekraczają $10 \%$.

\section{5. „Pytania do...”}

W ostatniej sekcji kwestionariusza - o nazwie „Pytania do...” - respondent mógł zadać trzy dowolne pytania dotyczące studiów filologicznych, które rozpoczyna. Pytania miały być skierowane do kierownictwa jednostki prowadzącej kierunek, jej wykładowców lub studentów starszych roczników. W tym przypadku celem badawczym było wyłonienie dodatkowych kwestii, jakimi interesują się studenci, poznanie ich ewentualnych obaw, ale też - pośrednio ustalenie, jakie potencjalne wyzwania stoją przed jednostką oferującą studia.

Raptem 5,2\% respondentów ( 25 osób) zadało łącznie 38 pytań - 10 pytań dotyczyło formalnych zasad studiowania (np. równoległego podejmowania studiów na dwóch kierunkach, warunków wyjazdu na stypendium, możliwości przejścia z grupy językowej początkującej do zaawansowanej w trakcie studiów), natomiast 28 pytań poświęcono innym kwestiom. Najczęściej pytano o perspektywy zawodowe. $W$ tej grupie można wyodrębnić kilka podgrup.

Pierwsza składa się z pytań bardziej ogólnych, np.:

- Czy te studia przyczyniq się do znalezienia satysfakcjonujqcej pracy? (R403);

- Jakie kursy/szkolenia warto odbyć, aby uzyskać wartościowe na rynku pracy dopełnienie do dyplomu kierunku germanistyka? (R83);

- Czy znajomość języka francuskiego zapewnia [...] mocna pozycję na rynku pracy? (R283).

Druga podgrupa to pytania dotyczące pracy za granicą, np.:

- Jakie sq możliwości pracy za granica z wykształceniem nauczycielskim [uzyskanym w Polsce]? (R387).

Trzecia podgrupa zawiera pytania o specyfikę konkretnego zawodu lub rodzaju pracy, np.:

- Czy po ukończeniu studiów łatwo odnajdę się w społeczeństwie tłumaczy? (R141); 
- Czy jest zapotrzebowanie na romanistów-freelancerów? (R283);

- W jakich instytucjach kulturalnych [...] najlepiej szukać pracy po anglistyce? (R407).

Kolejną grupę pytań skierowano do studentów starszych roczników lub absolwentów filologii, np.:

- Czy nie żałujesz podjęcia tego kierunku? (R121);

- Jakie sq losy studentów po moim kierunku, czym się zajmuja, gdzie pracuja i czy trudno im było zdobyć pracę? (R240).

Zaledwie kilka razy zadano pytanie o organizację studiów, ich przebieg i program, np.:

- Co dokładnie wyróżnia ten kierunek pośród innych? (R195);

- Które przedmioty sq najbardziej praktyczne i przydatne w przyszłości? (R267);

- Jak skutecznie przygotować się do egzaminów końcowych? (R7).

\section{Podsumowanie}

Ogólne spojrzenie na zgromadzone dane pozwala wywnioskować, że oczekiwania studentów rozpoczynających studia są - ze statystycznego punktu widzenia - konwencjonalne i wpisują się w tradycyjne kształcenie filologiczne. Jednak takie oczekiwania wynikają - zgodnie z moją oceną - ze społecznych reprezentacji studiów filologicznych w Polsce ${ }^{5}$. Filologia - w tym tradycyjnym ujęciu - to przede wszystkim nauka języka obcego (języków obcych), zdobywanie wiedzy o kulturze innych krajów (prawdopodobnie częściej przychodzi na myśl wiedza faktograficzna aniżeli umiejętności interkulturowe służące budowaniu symetrycznych relacji z przedstawicielami innych kultur), czytanie literatury obcej. Studia filologiczne mają przygotowywać głównie do wykonywania zawodów tłumacza i nauczyciela. Odmienny, chociaż rzadszy scenariusz to doskonałe opanowanie języka obcego, który ma być narzędziem w innej, niefilologicznej profesji, np. w pracy dyplomaty. Według analizy zebranych danych pobudki nieinstrumentalne odgrywają, jeśli nie kluczową, to bardzo ważną rolę w procesie decyzyjnym - satysfakcja wynikająca z nauki języków obcych, zgłębianie świata innych kultur, radość płynąca z czytania książek to tylko kilka z nich. Nawet gdy respondenci podają jako jeden z powodów podjęcia

${ }^{5} \mathrm{O}$ tym, jak postrzegane są studia filologiczne, mogą świadczyć opinie funkcjonujące w przestrzeni publicznej, jak również badania omawiane w wybranych i przytoczonych wcześniej publikacjach (np. Wróblewska-Pawlak, Okęcka, 2000; Paprocka-Piotrowska, Knieja 2009; Sowa, Mocarz-Kleindienst, Czyżewska, 2015). 
studiów perspektywę przygotowania do życia zawodowego, to częstokroć nie chodzi im o jasno zdefiniowaną, wiążącą się ze specyfiką konkretnego zawodu czy stanowiska wiedzę, ale o szeroko rozumiane przygotowanie humanistyczne, kompetencje komunikacyjne i różne umiejętności społeczne, które pozwalają stawiać czoła dynamicznie zmieniającej się różnokulturowej i różnojęzycznej rzeczywistości. Nie oznacza to rezygnacji z chęci nauki specjalistycznych odmian języków obcych bądź opanowania specyficznych umiejętności filologicznych (np. strategii translatorycznych), jednak dane nie potwierdzają, aby były to najistotniejsze motywy wyboru studiów filologicznych.

Zgromadzone wyniki można prezentować i interpretować różnorodnie, w zależności od celów badania, potrzeb społecznych, zainteresowań naukowych badacza itd. Formułując autorskie konkluzje, chciałbym przyjąć perspektywę decydentów w dziedzinie wyższego kształcenia filologicznego: urzędników, pracowników szczebla kierowniczego, nauczycieli akademickich itd. Zaprezentowane dane pokazują, że być może w mniejszym stopniu chodzi o „modernizowanie" treści kształcenia i zastępowanie tradycyjnych tematów filologicznych bardziej awangardowymi, a w większym stopniu o modyfikowanie metod i technik ich przekazywania, a także o inne rozłożenie akcentów, np. zastępowanie wykładów zajęciami interaktywnymi, rezygnowanie z nauczania chronologicznego na rzecz nauczania problemowego. Równocześnie - to prawdopodobnie najważniejszy wniosek - trzeba mieć na uwadze, że studenci rozpoczynający studia nie mogą konkretyzować swoich oczekiwań i planów, ponieważ nie znają materii, którą będą się zajmować podczas studiów. Posłużmy się banalnym przykładem: o ile każdy absolwent szkoły średniej wie, czym jest analiza tekstu literackiego i może antycypować przebieg zajęć z historii literatury, o tyle jest mu trudno wyobrazić sobie, jakie treści mogą się kryć pod hasłami „językoznawstwo" czy "glottodydaktyka" oraz jak będą przebiegać zajęcia z tych przedmiotów. Wiele oczekiwań i planów będzie się konkretyzować dopiero na skutek konfrontacji z danymi tematami. To zaś oznacza, że szeroko rozumiani decydenci - od urzędników ministerialnych po wykładowców przygotowujących sylabusy przedmiotów - mogą (powinni) kreować popyt i inspirować młodych ludzi do podejmowania nowych wyzwań, które wpisują się we współczesne kształcenie filologiczne. W moim odczuciu w obecnym momencie historii świata, przenikania się różnych kultur, społecznych prób i trudności w nawiązywaniu dialogów studia na filologiach mają swój specyficzny czas.

\section{BIBLIOGRAFIA}

Baran-Łucarz M. (2014), Podejście studentów filologii angielskiej do refleksji w nauce wymowy. „Neofilolog”, nr 42/1, s. 9-23 
Biernacka-Licznar K. (2013), Narracyjne studium życia na przykładzie studentów Wydziału Filologicznego Uniwersytetu Wrocławskiego. „Italica Wratislaviensia", nr 4, s. 9-27.

Dańko M., Wieszczeczyńska E. (2013), Wymogi współczesnego rynku pracy wodniesieniu do kompetencji absolwentów kierunków humanistycznych. „Neofilolog”, nr 40/1, s. 43-57.

Jaroszewska A. (2014), Sukces w nauce języka obcego w opinii studentów pierwszego roku warszawskiej germanistyki, (w:) Karpeta-Peć B., Kucharczyk R., Smuk M., Torenc M. (red.), Wyznaczniki sukcesu nauczyciela i ucznia w glottodydaktyce. Warszawa: Instytut Germanistyki i Instytut Romanistyki Uniwersytetu Warszawskiego, s. 283-294.

Lankiewicz H. (2013), Filologiczna praca licencjacka a rozwój kompetencji naukowych studenta. „Neofilolog”, nr 40/1, s. 111-125.

Nerlicki K. (2014), O sukcesach z perspektywy studentów germanistyki, którzy bojq się mówić, (w:) Karpeta-Peć B., Kucharczyk R., Smuk M., Torenc M. (red.), Wyznaczniki sukcesu nauczyciela i ucznia w glottodydaktyce. Warszawa: Instytut Germanistyki i Instytut Romanistyki Uniwersytetu Warszawskiego, s. 295-306.

Paprocka-Piotrowska U., Knieja J. (2009), Motywacje studentów neofilologii: od kandydata do absolwenta. „Przegląd Glottodydaktyczny”, nr 26, s. 159-172.

Pawlak M., Mystkowska-Wiertelak A., Bielak J. (2014), Przekonania studentów filologii angielskiej na temat nauczania gramatyki. "Neofilolog”, nr 42/1, s. 77-93.

Pudo D. (2017), Subiektywne teorie na temat uczenia się języka obcego studentów romanistyki. „Neofilolog”, nr 48/1, s. 55-71.

Sowa M., Mocarz-Kleindienst M., Czyżewska U. (red.) (2015), Nauczanie języków obcych na potrzeby rynku pracy. Lublin: Wydawnictwo KUL.

Werbińska D. (2012), Akwizycja języka obcego w perspektywie studenta filologii: badanie tożsamości narracyjnej studenta $w$ kontekście czasoprzestrzeni i heteroglosji. „Neofilolog”, nr 39/1, s. 55-80.

Wróblewska-Pawlak K., Okęcka H. (2000), Socjologiczny portret studentów romanistyki UW: motywacje, wyobrażenia, plany i potrzeby, (w:) Okęcka H., Wróblewska-Pawlak K., Zając J. (red.), Le français langue étrangère à l'université - nouveaux objectifs, nouveaux besoins. Instytut Romanistyki Uniwersytetu Warszawskiego: Warszawa, s. 57-85. 